\title{
Effect of Computer-Based Software Package on Students' Achievement in Graphical Concepts in Mathematics
}

\author{
Udobia Elijah Etukudo \\ Department of Mathematics, Federal College of Education (Technical), Omoku, Rivers State, Nigeria \\ e-mail: udobiaetukudo@gmail.com
}

\begin{abstract}
Abstrak
Penelitian ini bertujuan untuk menentukan pengaruh paket program software komputer (CBSPP) bagi pengguna komputer reguler (RUC) dan pengguna komputer non reguler (IUC) terhadap prestasi belajar siswa pada materi konsep grafik di matematika. Penelitian ini juga meneliti pengaruh variabel moderator berupa self-efficacy komputer dan gender. Penelitian ini berdasarkan pada kerangka teori Skinner dengan mengadopsi penelitian kuasi eksperimen pretest-posttest control grup design. Sebanyak 296 siswa dari enam sekolah menengah atas dipilih secara purposive, yaitu di daerah Ogba (3), Egbema (2), dan Ndoni (1), di Rivers State, Nigeria berdasarkan ketersediaan komputer. Masing-masing dua kelas dari setiap sekolah menengah atas dijadikan sebagai RUC sebanyak 97 siswa dan diberi laptop selama penelitian berlangsung, 99 siswa menjadi IUC, dan 100 siswa menjadi kelompok kontrol. Instrumen yang digunakan adalah tes prestasi belajar materi konsep grafik $(r=0.83)$ dan skala self-efficacy komputer $(r=0.81)$. Selain itu, peneliti juga menyediakan pedoman instruksional. Data dianalisis menggunakan analisis kovarians dan uji lanjut Scheffe dengan taraf nyata $\alpha=0.05$. Hasil penelitian menunjukkan bahwa ada pengaruh signifikan perlakuan terhadap prestasi belajar. Selain itu, ada pengaruh signifikan selfefficacy komputer terhadap prestasi belajar dan gender terhadap prestasi belajar. Terdapat interaksi dua arah yang signifikan antara perlakuan dengan self-efficacy komputer, perlakuan dengan gender, serta self-efficacy komputer dan gender secara bersama-sama terhadap hasil belajar. Terdapat pula interaksi tiga arah yang signifikan antara perlakuan, self-efficacy komputer, dan gender terhadap prestasi belajar di kelompok RUC.
\end{abstract}

Kata Kunci: paket program software komputer, pengguna komputer reguler, pengguna komputer non reguler, prestasi belajar materi konsep grafik

\begin{abstract}
This study determined the effects of the Computer Based Software Program Package (CBSPP) for Regular Users of Computer (RUC) and Irregular Users of Computer (IUC) on students' achievement in graphical concepts in mathematics. It also examined the moderating effects of computer selfefficacy and gender. Skinner's behaviorist theory provided the framework, while the pretestposttest control group quasi-experimental design with $3 \times 3 \times 2$ factorial matrix was adopted. Two hundred and ninety-six senior secondary II (SS II) students were purposively selected from six schools in Ogba (3), Egbema (2) and Ndoni (1) Local Government Area of Rivers State, Nigeria based on the availability of the computer. Two whole classes each of SS II totaling 97students were randomly assigned to the RUC and given laptop computers to use for the period of the experiment, IUC (99 students) and control group (100 students). Instruments used were: achievement test on the graphical concept $(r=0.83)$ and computer self-efficacy $(r=0.81)$ scales. Instructional guides were also used. Data were analyzed using analysis of covariance and Scheffe post-hoc test at $\alpha=$ 0.05 . There were significant main effects of treatment on achievement. There were significant main effects of computer self-efficacy on students' achievement and gender on achievement. There were significant two-way interaction effects of treatment and computer self-efficacy, treatment and gender, computer self-efficacy and gender on students' achievement. There were significant threeway interaction effects of treatment, gender and computer self-efficacy on students' achievement in favor of the RUC.
\end{abstract}

Keywords: computer-based software program package, regular users of computer, irregular users of computer, achievement in graphical concepts in mathematics 
How to Cite: Etukudo, U. E. (2018). Effect of Computer-Based Software Package on Students' Achievement in Graphical Concepts in Mathematics. International Journal on Emerging Mathematics Education, 2(2), 139-156. http://dx.doi.org/10.12928/ijeme.v2i2.8680

\section{INTRODUCTION}

Mathematics is a subject needed in every aspect of human life. It is an area of knowledge used by all people throughout the world such that no activity or development can take place without mathematics. The achievement of mathematics, therefore, is important (Reyna \& Brainerd, 2007). However, the performance of students in the subject is consistently poor (Ashikia, 2010; Areelu \& Akinsola, 2014; Tella, 2007) Many argue that fear, lack of appreciation, teachers' attitude, method and poor educational system are responsible for students poor performance in the subject in Nigeria.

One of the causes is the method of mathematics teaching. It is essential to device effective strategy in order to reduce the problem of phobia associated with learning mathematics and the poor performance as its consequence. Ashikia (2010) affirmed that teachers' methods of teaching are among the factors that influence students' performance in mathematics. It is, therefore, not disputable that methods of teaching are among the major causes of students' poor performance in mathematics (Faulkner, 2008; Areelu \& Akinsola, 2014; Akinsola \& Odeyemi, 2014).

The performance of students in mathematics examination has been confirmed to be on the downward trend with $65.3 \%$ still scoring between $0 \%$ and $39.9 \%$ (WAEC, 2014). The poor performance of students in Mathematics remains a problem as only $36 \%$ of the students sat for examinations conducted by West African Examinations Council passed mathematics at credit level in 2011, 38\% in 2012 and 29\% in 2013 (WAEC, 2013). The source of difficulty experienced by students according to Chief examiner's report is that students demonstrated a severe deficiency of mensuration, circle theorems, trigonometry, geometrical constructions, statistics and graphs (WAEC, 2016). Though one would have thought that students should well receive a drawing of graphs and interpretationstudents, however, the majority of the students could not interpret the graphs correctly.

Students have poor knowledge of the difference between bar charts and histograms and are also unable to plot points on the graph of quadratic expression and ogives. From examinations conducted in 2007, 2008, 2009 and 2010 it was reported that majority of the students who answered questions on graphs of quadratic expressions were unable to use the graphs correctly to solve equations, read and draw inference from the graph, draw the tangent to the curve and determine the gradient (WAEC, 2017). The performance of students on the construction of graphs of trigonometric functions was also reported to be very poor as students were reported to be unable to either complete the table of values correctly or draw the graphs well (WAEC, 2017). The performance of students on the drawing of graphs of cumulative frequency was another area of the problem identified as students were reported to be unable to either use the correct points for the graphs or properly determine the values that were required (WAEC, 2017). Drawing and interpretation of graph of trigonometry function was a source of difficulty for students (WAEC, 2016), those attempted question on the topic performed poorly. Therefore, adopting better instructional strategies in teaching is necessary (Hooper \& Rieber, 1995).

Specifically, graph construction and interpretation is an area of mathematics in which many students are deficient. They lack the mental tools to engage in severe

IJEME, Vol. 2, No. 2, September 2018, 139-156. 
construction and interpretation of graphs, even though graph is essential in the representation of mathematical fact, ideas, and concepts (Roth \& McGinn, 1997). Berg \& Smith (2006) equally emphasized the relevance of graph construction and interpretation in everyday life and decried the poor performance of students in the questions involving graphs. They reasoned that both multiple choice and essay type items could be used in testing students' graphing ability for both boys and girls. Aoyama (2007) reported from a study that all the participants performed very poorly at all levels of graph interpretation, a situation described as catastrophic considering the importance of graph interpretation in the economy. Thus, students need to know how to critique data and present same as tables and graphs are relevant to all aspects of the curriculum. However, report shows that they have the problems of extracting and interpreting information; constructing and completing graphs and tables; giving appropriate title to tables and graphs; inability to label the axes correctly; difficulty of working with one variable at a time; understanding the language of graphs and table; construction of tables of values; transforming data from text as well as interpolation and extrapolation.

Knuth (2000) studied students understanding of graph as well as the way they answer questions involving graphs and noted that students' knowledge of the relationship between graph and functions is limited such that while students can create graphs from functions they cannot create functions from graphs and hence, are fond of using functions to answer questions on graphs. Considering the importance of graphing in economic, scientific and technological development, it is crucial that methods that will improve graphing skills of learners should be employed in teaching the concept. Konold \& Higgins (2003) suggested that to enable students to understand graphs, and they should be made to carry out all steps of data analyses and graphing and explore different types of graphs. Parmar \& Signer (2005) concluded from a study of 91 students that notwithstanding difficulties students have with graph construction and interpretation, continuous practice and familiarity with data would help them to master the concepts. Vernadakis et al. (2005) posited that the use of computerassisted instruction helps the learners in understanding concept and skills of graphs and table and are useful in imparting the desired learning experience.

\section{Problem Statement}

The poor performance of students in mathematics in public examination has been a thing of concern. Although mathematics is a core and compulsory subject at the secondary school level of education and also a prerequisite for gaining admission into many disciplines in the tertiary institutions in Nigeria, achievement of students in mathematics has been reported to be consistently poor. One of the topics in mathematics in which students' poor performance is noticed is the graph. Students' achievement graphs are unsatisfactory. Students are observed to lack the relevant knowledge and skill of constructing and interpreting graphs of quadratic expression, trigonometric functions and cumulative frequency (ogives). The cause of this may be partly due to the continuous use of conventional teaching strategy in secondary schools to teach graphs.

Despite regular workshops, seminars and other forms of in-service training conducted by Mathematical Association of Nigeria (MAN), National Mathematical Centre (NMC), National Teachers Institute (NTI) and other agencies at states and national level for teachers of mathematics on ways of improving the teaching of mathematics, has not yielded desired result. The teachers are still using a conventional 
strategy which cannot help the situation. The use of computer-based software packages in teaching graphical concepts in mathematics is not popular among secondary school teachers in Nigeria. In this study, computer-based software packages are used in teaching graphs to investigate their effects on achievement of learners while adopting computer self-efficacy and gender as moderating variables.

\section{Hypothesis}

Based on the above-stated problem, the following hypotheses are tested at the 0.05 significance level.

1. $H_{01}$ : There is no significant main effect of treatments (the use of computer-based software package) on students' achievement in graphs.

2. $H_{02}$ : There is no significant main effect of computer self-efficacy on students' achievement in graphs.

3. $H_{03}$ : There is no significant main effect of gender on students' achievement in graphs.

4. $H_{04}$ : There is no significant interaction effect of treatment and computer selfefficacy on students' achievement in graphs.

5. $H_{05}$ : There is no significant interaction effect of treatment and gender on students' achievement in graphs.

6. $H_{06}$ : There is no significant interaction effect of gender and computer self-efficacy on students' achievement in graphs.

7. $H_{07}$ : There is no significant interaction effect of treatment, gender and computer self-efficacy on students' achievement in graphs.

\section{Scope of Study}

The study examined the effect of a computer-based software package on students' learning outcomes in graphs in selected senior secondary schools in Ogba, Egbema and Ndoni Local Government Area of Rivers State. Areas of concentration include graphs of quadratic expression, trigonometry functions (graphs of the sine of angles, cosines of angles, tangents of angles) and graphs of cumulative frequency (ogives). Also, solutions to quadratic equations by graphical methods, plotting, and interpretation of graphs, calculation of the gradient and intercept of graphs, calculation of maxima and minima of functions using graphs and location of points on the curves were treated. The moderating effects of gender and computer self-efficacy on students' achievement are also determined.

\section{The Significance of the Study}

This study is of immense contribution to the mathematics and science teachers in general, students and researchers in mathematics and mathematics education, government, curriculum planners, and developers. The study provides empirical evidence on the use of computer-based software package in teaching graphical concepts in mathematics.

The study enables the curriculum planners and the government to assess the possibility of including a computer as essential tools for use in teaching mathematics and equally train mathematics teachers on effective use of the computer in the classroom. The study paves the way for the need to incorporate computer programming into mathematics teachers training curriculum to equip them with the development and use of computer-based packages for effective teaching of mathematics. 
The study exposes learners to a strategy that enables them to participate actively in the educational process and working on their pace using a computer to acquire skills which are not available in the conventional strategy. With the help of the computer, the learners can learn graphical concept actively.

The study exposes teachers to the alternative and effective strategy of teaching graphical concepts in mathematics. It will also encourage further researches and initiate the interest of researchers in Mathematics education on the necessity of conducting similar studies in Mathematics and other science subjects.

\section{RESEARCH METHOD Research Design}

This study adopted a pretest-posttest, control group, quasi-experimental design with a $3 \times 3 \times 2$ factorial matrix as shown in Table 1 .

Table 1 . The $3 \times 3 \times 2$ factorial matrix

\begin{tabular}{|c|c|c|c|c|c|}
\hline \multirow{2}{*}{$\mathrm{S} / \mathrm{N}$} & \multirow{2}{*}{ Treatment $(\mathrm{X})$} & \multirow{2}{*}{$\begin{array}{l}\text { Gender } \\
\text { (Y) }\end{array}$} & \multicolumn{3}{|c|}{ Computer self -efficacy (Z) } \\
\hline & & & Low & Medium & High \\
\hline \multirow[t]{2}{*}{1.} & Interactive basic programme & Male & $\mathrm{X}_{1} \mathrm{Y}_{1} \mathrm{Z}_{1}$ & $\mathrm{X}_{1} \mathrm{Y}_{1} \mathrm{Z}_{2}$ & $\mathrm{X}_{1} \mathrm{Y}_{1} \mathrm{Z}_{3}$ \\
\hline & package instruction strategy & Female & $\mathrm{X}_{1} \mathrm{Y}_{2} \mathrm{Z}_{1}$ & $\mathrm{X}_{1} \mathrm{Y}_{2} \mathrm{Z}_{2}$ & $\mathrm{X}_{1} \mathrm{Y}_{2} \mathrm{Z}_{3}$ \\
\hline \multirow[t]{2}{*}{2.} & Graphing organizer aided & Male & $\mathrm{X}_{2} \mathrm{Y}_{1} \mathrm{Z}_{1}$ & $\mathrm{X}_{2} \mathrm{Y}_{1} \mathrm{Z}_{2}$ & $\mathrm{X}_{2} \mathrm{Y}_{1} \mathrm{Z}_{3}$ \\
\hline & instruction strategy & Female & $\mathrm{X}_{2} \mathrm{Y}_{2} \mathrm{Z}_{1}$ & $\mathrm{X}_{2} \mathrm{Y}_{2} \mathrm{Z}_{2}$ & $\mathrm{X}_{2} \mathrm{Y}_{1} \mathrm{Z}_{3}$ \\
\hline \multirow[t]{2}{*}{3.} & Conventional teaching & Male & $\mathrm{X}_{3} \mathrm{Y}_{1} \mathrm{Z}_{1}$ & $\mathrm{X}_{3} \mathrm{Y}_{1} \mathrm{Z}_{2}$ & $\mathrm{X}_{3} \mathrm{Y}_{1} \mathrm{Z}_{3}$ \\
\hline & strategy & Female & $\mathrm{X}_{3} \mathrm{Y}_{2} \mathrm{Z}_{1}$ & $\mathrm{X}_{3} \mathrm{Y}_{2} \mathrm{Z}_{2}$ & $\mathrm{X}_{3} \mathrm{Y}_{2} \mathrm{Z}_{3}$ \\
\hline
\end{tabular}

The variables in the study are includes independent variable of the instructional strategy varied as computer-based programmed package strategy (1) for students that have no access to computer for learning after school (Irregular Users of ComputerIUC), (2) students that use computer for learning after school (Regular User of Computer-RUC), and (3) conventional strategy. The moderator variables include (1) computer self-efficacy (high, moderate and low) and (2) students gender (male and female). The dependent variable is students' academic achievement in graphs.

\section{Selection of Participants}

Six secondary schools in Ogba, Ndoni, and Egbema local Government of Rivers State were selected for the study based on the criteria that the SS2 mathematics teachers must be ready to be involved in the experiment, the schools must be coeducational, the students must not have been taught the topics selected for the study, the schools must have a computer laboratory with desktops or laptop computers that are in excellent condition or located close to a computer centres that are within a walking distance. One whole class of SS2 was randomly selected from each school making a total of six whole classes. The whole classes were randomly assigned to treatment and control groups. Two whole classes each of SS II students were randomly assigned to the RUC(97) and given laptop computers to use for the period of the experiment, IUC (99 students) and control group (100 students). A total of 296 SS2 students, 153 males, and 143 females participated in the study. The group was further segmented based on computer self-efficacy to low 68 students (26 males and 42 
females), moderate 99 students (52 males and 47 females) and high 129 students (75 males and 54 females).

The ages of the participants varied from thirteen (13) to seventeen (17) years. Majority of the students were of fifteen (15) years of age. The participants had a mean age of fifteen (15) and a standard deviation of 1.025 years. This is because the minimum year of entry to secondary school in Nigeria is eight (8) years since few children start primary school at the age of two (2) years.

\section{Research Instruments}

The instruments used for data collection were: Students Achievement Test on Graphs (SATOG); Computer Self Efficacy Scale (CSES), Computer Based Software Program Package Instruction (CBSPPI) for RUC and IUC; Instructional Guide for (CBSPPI); Instructional Guide for conventional classroom Instruction on Graphs (CCIG). Students Achievement Test on Graphs (SATOG), comprised of 50 multiple choice questions selected from a group of 150 items used for the pilot study. The distributions of the items were as given in Table 2.

Table 2. Specification for achievement test on graphs

\begin{tabular}{cccccc}
\hline Content & $\begin{array}{c}\text { Quadratic } \\
\text { expression }\end{array}$ & $\begin{array}{c}\text { Trigonometry } \\
\text { graph }\end{array}$ & $\begin{array}{c}\text { Inequality } \\
\text { graph }\end{array}$ & $\begin{array}{c}\text { Cumulative } \\
\text { frequency }\end{array}$ & Total \\
\hline \multirow{2}{*}{ Memory } & 2 & 2 & 2 & 2 & 8 \\
Comprehension & $(1,2)$ & $(17,18)$ & $(27,28)$ & $(38,39)$ & \\
& 2 & 2 & 1 & 1 & 6 \\
Application & $(3,4)$ & $(19,20)$ & $(29)$ & $(42)$ & \\
& $(5,6,7)$ & $(21,22,23)$ & $(30,33)$ & $(40,41,43)$ & 11 \\
Analysis & 2 & 1 & 2 & 2 & 7 \\
Synthesis & $(8,9)$ & $(24)$ & $(31,32)$ & $(44,45)$ & \\
& 4 & 1 & 2 & 2 & 9 \\
Evaluation & $(10,11,12)$, & $(25)$ & $(34,35)$ & $(46,47)$ & \\
& 4 & 1 & 2 & 2 & 9 \\
Total & $(13,14,15,1$ & $(26)$ & $(36,37)$ & $(48,49)$ & \\
\hline
\end{tabular}

The items were further spread into the following sections, construction of table of values, plotting of points on the graphs, construction of the curves, interpretation of the graphs, determination of minima and maxima of curves, determination of gradient and intercept of the curves, finding solution to the equations, determination of point of intersection with curves and lines. Both the pretest and the posttest were the same in all ramifications and were given before and after the treatments respectively. They were written for one hour thirty minutes. Each correct option attracted a score of 2 marks. The test items were validated and had difficulty index of $25 \%$ to $70 \%$ and discriminating power of $0.5-0.6$ as well as the coefficient of stability of 0.83 from testretest of 14 days.

Computer self-efficacy of twenty-five items was designed and given to all the students. The test concentrates on the subjects' knowledge of computer; ability to apply computer and their frequency of using a computer. It was given before the 
experiment for thirty minutes. The scale was scored over 25 and converted to $100 \%$. Scores of $0-40$ were classified as low, $40-69$ moderate and $70-100$ high. A testretest of 14 days was conducted on Computer Self Efficacy of the subjects and coefficient of reliability of 0.81 obtained.

Computer Based Software Program Package Instruction (CBSPPI) used in this study were written using QBASIC on graphs of quadratic expression, graphs of trigonometry function and graphs of cumulative frequency. They were used to teach the IUC and RUC, each package lasted for ten days of the 45 minutes lesson each day and giving a total of two weeks per package and six weeks for the three packages. The inter-rater reliability coefficient of 0.85 was obtained for the packages.

There were lesson plans on each of the sub-topics of graphs treated in this study for conventional classroom Instruction on Graphs (CCIG). The area covered included graph of quadratics expression, graphs of a trigonometric function and Ogives or graphs of cumulative frequency. The lessons plans had inter-rater reliability coefficient of 0.83 .

\section{Package Development}

The development of this instructional package is based on Isman (2011) model for instructional design. The framework is based on the task facing any instructional package developer or evaluator. The salient features incorporated into the package to make it successful (promote effective learning) include: (1) input which involves identification of needs, contents, goals- objectives, methods, materials and media; (2) process which includes preparation of test prototypes, redesigning of instruction and teaching activities; (3) output which involves testing and analyzing the results; (4) feedback which involves revising the instruction; and (5) enhancing effective learning.

At the input stage, the students' needs are identified to include understanding and being able to define graphs and the associated concepts such as gradients, intercepts, minimum and maximum values, table of values, coordinates and axes. The learners need to be able to plot point in the Cartesian coordinates correctly, draw the graphs neatly and accurately as well as use it to solve problems. The learners also cultivated a positive attitude towards graphs. The content includes graphs of quadratic expression, trigonometric functions, and ogives. At the end of the lessons, the learners were able to draw and interpret the graphs of quadratic expression, trigonometric functions, and ogives, and use them to solve problems. The learning took place both in the computer laboratory and classroom. Desktop computers, graph books, pen, paper, erasers, and charts were used in the interactive session which included-discussion, drill, and simulation.

The process involved the preparation of the different test items which were used to measure the effectiveness of the learning. The various instruments validated at this stage were redesigned for actual teachings which were carried out as stated in the procedure. Output stage involved formative evaluations which were done as the teaching and learning progress on which bases the revisions were carried out. The results of all formative evaluations were given to the learners, as feedback, and corrections made as the learning progresses. The summative evaluation which in this case was the posttest gave the result of the actual learning outcome.

\section{Treatment Procedure}

The pretest on the two primary instruments for data collection, Students Achievement Test on Graphs (SATOG), Computer Self Efficacy (CSE), were 
administered by the researcher, the trained teachers, and other research assistants to each of the three groups in the fourth week.

After the pretest, the subjects in the Computer-Based Software Program Package Instruction (CBSPPI) groups ( RUC and IUC) were made to interact with the computer and taught how to carry out the preliminary operations like starting the computer, scrolling through documents using the arrow keys and running a given program by pressing $f_{5}$ key. The subjects in the RUC were given laptop computers to use throughout the treatment even after the lessons. The experiment continued with a lesson on graphs of quadratic expressions, linear and quadratic inequalities at the end which the subjects were given the print out to go. This lasted for two weeks. The lessons on graphs of trigonometry functions and the cumulative frequency graphs lasted for two weeks each. All the lessons took place in five consecutive days starting from Monday to Friday each week between the hours of $3.30 \mathrm{pm}$ to $5.30 \mathrm{pm}$ after the normal school period.

Computer Based Software Program Package (CBSPP) experiment comprised complete interactive processes which included introduction of the learners to the computer and it various parts that will be used in the class, familiarizing the students with essential keys that they manipulated during learning, opening the CD and running the package, definition of concepts, asking and answering questions, explaining the concepts using the package, explaining the examples from the package and answering questions, copying the graphs from the package and drawing similar graphs on the graph papers, answering the drill questions from the package and scoring oneself, summary and homework or assignments, scoring of answers to homework and assignments.

After the pretests, the subjects in the controlled group $\mathrm{C}$ were made to learn how to construct and interpret graphs and general concepts and terminology on graphs. This was followed by lessons on graphs of quadratic expressions, linear and quadratic inequalities involving drawing and interpretation of the graph using graph book and grid tracing paper. This lasted for two weeks. The lessons on graphs of trigonometry functions and cumulative frequency graphs lasted for two weeks each. All the lessons took place in five consecutive days each week starting from Monday to Friday between the hours of $3.30 \mathrm{pm}$ to $5.30 \mathrm{pm}$ after the normal school period. The CCIG comprised complete interactive processes which included a definition of concepts, explanations, questioning and answering, drawing and sketching, calculating and interpretation of data, summary and homework or assignments.

The posttest on Students Achievement Test on graphs (SATOG) was administered by the researcher, the trained teachers, and other research assistants to each of the three groups in the last week.

\section{Data Analysis}

Analysis of Covariance (ANCOVA) was used for the testing of the hypotheses, while multiple classification analysis (MCA) was used to determine the magnitude of the mean scores of various groups and Sheffe's post hoc test was used to determine the source of the significance of main effects and where they are significant interaction. 


\section{RESULTS AND DISCUSSION}

\section{Effect of Treatment towards Students' Achievement}

The result of the first hypothesis testing is presented in Table 3. The $H_{01}$ says that there is no significant main effect of treatment on students' achievement in graphs.

Table 3. Summary of $3 \times 3 \times 2$ analysis of covariance (ANCOVA) of posttest achievement by treatment, gender, and computer self-efficacy

\begin{tabular}{lrrrrrr}
\hline \multicolumn{1}{c}{ Source } & $\begin{array}{c}\text { Type III Sum } \\
\text { of Squares }\end{array}$ & df & \multicolumn{1}{c}{$\begin{array}{c}\text { Mean } \\
\text { Square }\end{array}$} & \multicolumn{1}{c}{ F } & Sig. & $\begin{array}{c}\text { Partial Eta } \\
\text { Squared }\end{array}$ \\
\hline Corrected Model & $27001.574^{\mathrm{a}}$ & 17 & 1588.328 & 138.972 & .000 & .895 \\
Intercept & 840775.518 & 1 & 840775.518 & 73564.43 & .000 & .996 \\
Treatment & 15502.982 & 2 & 7751.491 & 678.224 & $.000^{*}$ & .830 \\
Gender & 80.409 & 1 & 80.409 & 7.035 & $.008^{*}$ & .025 \\
Self-efficacy & 6878.234 & 2 & 3439.117 & 300.909 & $.000^{*}$ & .684 \\
Treatment x & 87.861 & 2 & 43.930 & 3.844 & $.023^{*}$ & .027 \\
Gender & 1416.956 & 4 & 354.239 & 30.994 & $.000^{*}$ & .308 \\
Treatment x Self- & & & & & & \\
efficacy & 70.247 & 2 & 35.123 & 3.073 & $.048^{*}$ & .022 \\
Gender x Self- & 109.464 & 4 & 27.366 & 2.394 & $.051^{*}$ & .033 \\
efficacy & & & & & & \\
Treatment x & & & & & & \\
Gender x Self- & 3177.291 & 278 & 11.429 & & & \\
efficacy & 1031964.000 & 296 & & & & \\
Error & 30178.865 & 295 & & & & \\
Total & & & & & & \\
Corrected Total & & & & & & \\
\hline
\end{tabular}

a. R Squared $=.895$ (Adjusted R Squared $=.888$ ) $*$ Significant at $p<0.05$

Table 3 shows that there is a significant effect of treatment on students' posttest score in graphs $\left(\mathrm{F}_{(2,295)}=678.224\right.$; Partial $\left.\eta^{2}=0.83\right)$. Therefore the $H_{01}$ is rejected. In order to determine the magnitude of achievement mean scores across the groups, the marginal mean scores of the groups are presented in Table 4.

Table 4. Estimated marginal mean scores of students' achievement across the group

\begin{tabular}{lccc}
\hline \multicolumn{1}{c}{ Treatment } & $\mathrm{N}$ & Mean & Std. Error \\
\hline CONTROL (Conventional Strategy) & 100 & 49.669 & .353 \\
RUC & 97 & 67.288 & .353 \\
IUC & 99 & 53.639 & .382 \\
\hline
\end{tabular}

Table 4 reveals that students exposed to interactive basic program package had higher achievement mean score (67.288) than those exposed to the graphic organizer (53.639) and the conventional strategy (49.669). This information is represented in Figure 1. 


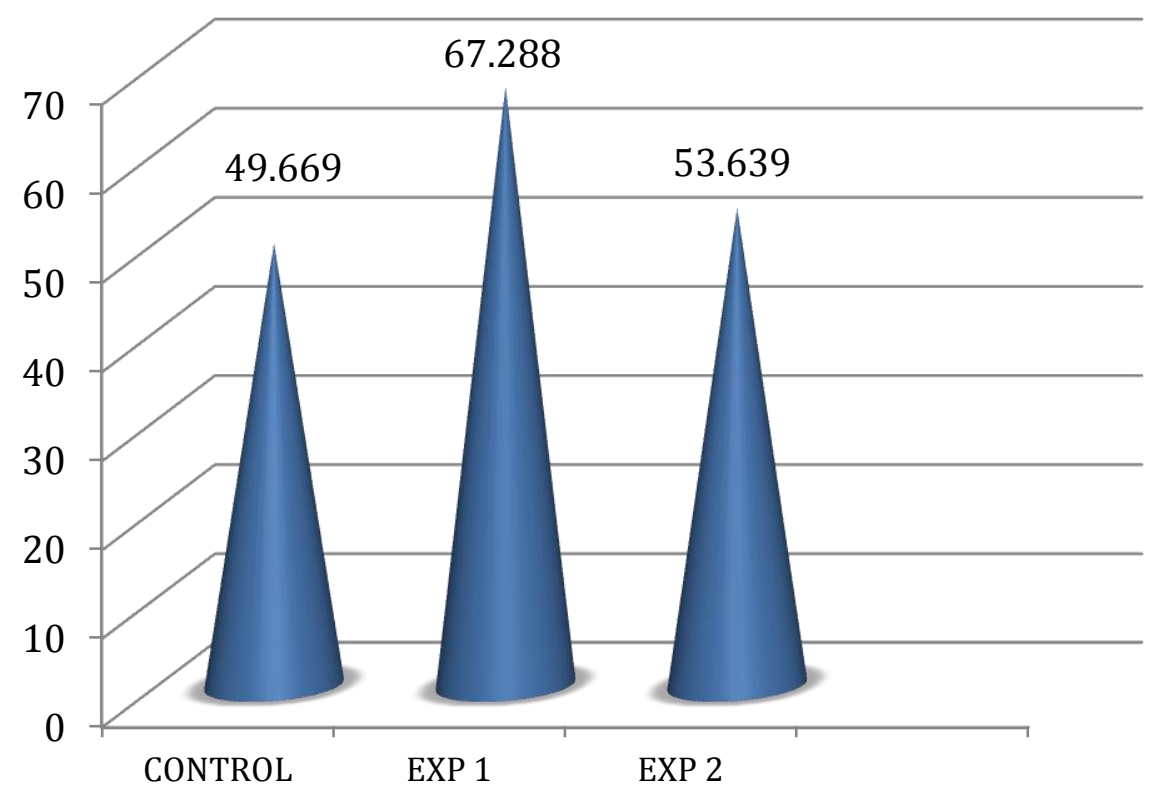

Figure 1. Pictorial representation of the adjusted posttest achievement scores across the groups

To determine the source of significant difference among the three groups, Table 5 presents the pairwise comparison of the Scheffe post hoc test carried out.

Table 5. Scheffe pairwise comparison of posttest achievement across the groups

\begin{tabular}{lcccc}
\hline Treatment & Mean Score & Control & Exp.1 & Exp. 2 \\
\hline Control & 49.669 & & $*$ & $*$ \\
RUC & 67.288 & $*$ & & $*$ \\
IUC & 53.639 & $*$ & $*$ & \\
\hline
\end{tabular}

${ }^{*}$ pairs of groups significantly different at $p<0.05$

Table 5 shows that the significant difference obtained in table 3 is as a result of the significant difference between the control group and RUC; Control group and IUC; RUC and IUC. This implies that students exposed to Computer Based Software Program Package Instruction (CBSPPI) performed significantly better than Conventional Strategy. It is also clear that the RUC performed significantly better than IUC. As a result, all three pairs of groups contributed significantly to the effect of treatment on achievement.

\section{Effect of Treatment towards Students' Achievement}

The result of the second hypothesis testing is also presented in Table 3 . The $H_{02}$ says that there is no significant main effect of Computer Self-Efficacy on students' Achievement in graphs. From Table 3, it is observed that there is the significant main effect of Computer Self Efficacy on students' achievement in graphs $\left(\mathrm{F}_{(2,295)}=300.909\right.$; partial $\left.\eta^{2}=0.68\right)$. Therefore hypothesis $H_{02}$ is rejected. There is a significant difference in the achievement of students with high, moderate and low computer skills, grouped from the computer self-efficacy given before the treatment. The differences in computer self-efficacy after the experiment for RUC and IUC though significance was not integrated into this study because of its size, and the article is 
already very large. The estimated marginal mean achievement score on the bases of the various computer self-efficacies is shown in Table 6.

Table 6. Estimated marginal mean achievement scores of students with low, moderate and computer self-efficacy

\begin{tabular}{lrcr}
\hline \multicolumn{1}{c}{ Computer self-efficacy } & N & Mean & Std. Error \\
\hline Low & 68 & 50.511 & .423 \\
Moderate & 99 & 56.910 & .347 \\
High & 129 & 62.565 & .310 \\
\hline
\end{tabular}

Table 6 shows that students with high computer skills had higher achievement mean score (62.57) than those with moderate computer skills (56.91) and low computer skills (50.51); whereas those with moderate computer skills performed better than students with low computer skills. The representation of Achievement scores based on the levels of computer self-efficacy is given in Figure 2.

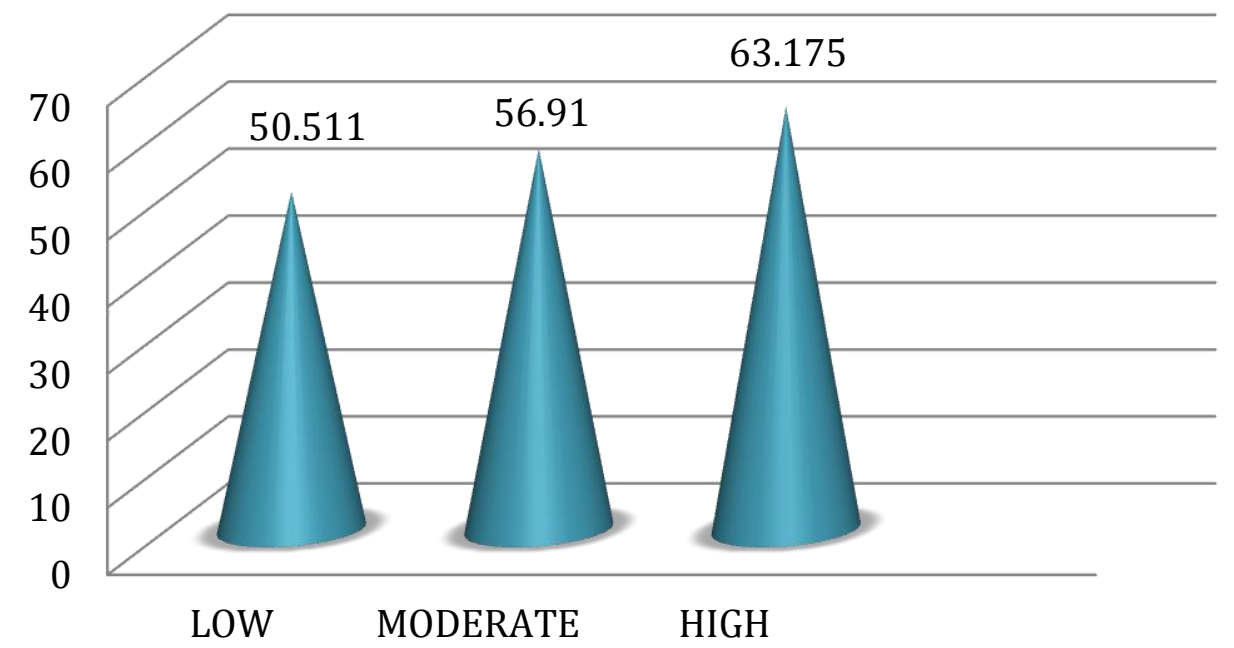

Figure 2. Pictorial representation of the adjusted posttest achievement scores across the different levels of computer self-efficacy

To determine the source of significant difference among the three levels of computer self-efficacy, Table 7 presents the pairwise comparison of the Scheffe post hoc test carried out.

Table 7. Scheffe pairwise comparison of posttest achievement across the levels of computer self-efficacy

\begin{tabular}{llccc}
\hline $\begin{array}{c}\text { Computer } \\
\text { Self-efficacy }\end{array}$ & Mean Score & Low & Moderate & High \\
\hline Low & 49.669 & & $*$ & $*$ \\
Moderate & 67.288 & $*$ & $*$ & $*$ \\
High & 53.639 & $*$ & $*$ & \\
\hline \multicolumn{5}{r}{ *pairs of groups significantly different at $p<0.05$}
\end{tabular}

Table 7 shows that the significant difference is due to the significant difference in the achievement scores between students with low and high computer skills; moderate and high computer skills; and low and moderate computer skill. 


\section{Effect of Gender on Students' Achievement}

The result of the third hypothesis testing is also presented in Table 3. The $H_{03}$ says that there is no significant main effect of effect of gender on students' Achievement in graphs. Table 3 reveals that there is significant main effect of gender on students' achievement on graphs $\left(\mathrm{F}_{(1,295)}=7.035\right.$; partial $\left.\eta^{2}=0.25\right)$. Therefore $H_{03}$ is rejected. Table 8 shows the estimated mean achievement of male and female students in graphs. The raw scores difference is about 733 which is why the difference is significant despite the closeness of the mean.

Table 8. Estimated marginal mean achievement scores of male and female students

\begin{tabular}{|c|c|c|c|}
\hline Gender & $\mathrm{N}$ & Mean & Std. Error \\
\hline Male & 153 & 57.421 & .291 \\
\hline Female & 143 & 56.309 & .302 \\
\hline
\end{tabular}

From Table, eight male students obtained higher achievement mean score (57.42) than their female counterpart (56.31).

\section{Effect of treatment and computer self-efficacy on Students' Achievement}

The result of the fourth hypothesis testing is also presented in Table 3. The $H_{04}$ says that there is no significant interaction effects of treatment and computer selfefficacy on students' Achievement in graphs. Table 3 reveals that there is significant interaction effect of treatment and computer self-efficacy on students' Achievement in graphs $\left(\mathrm{F}_{(4,295)}=30.99\right.$; partial $\left.\eta^{2}=0.31\right)$. Therefore $\mathrm{HO}_{4}(\mathrm{a})$ is rejected. Figure 3 shows the interaction effect. At all levels, the achievement in EXP 1 (RUC) was higher, followed by EXP 2 (IUC).

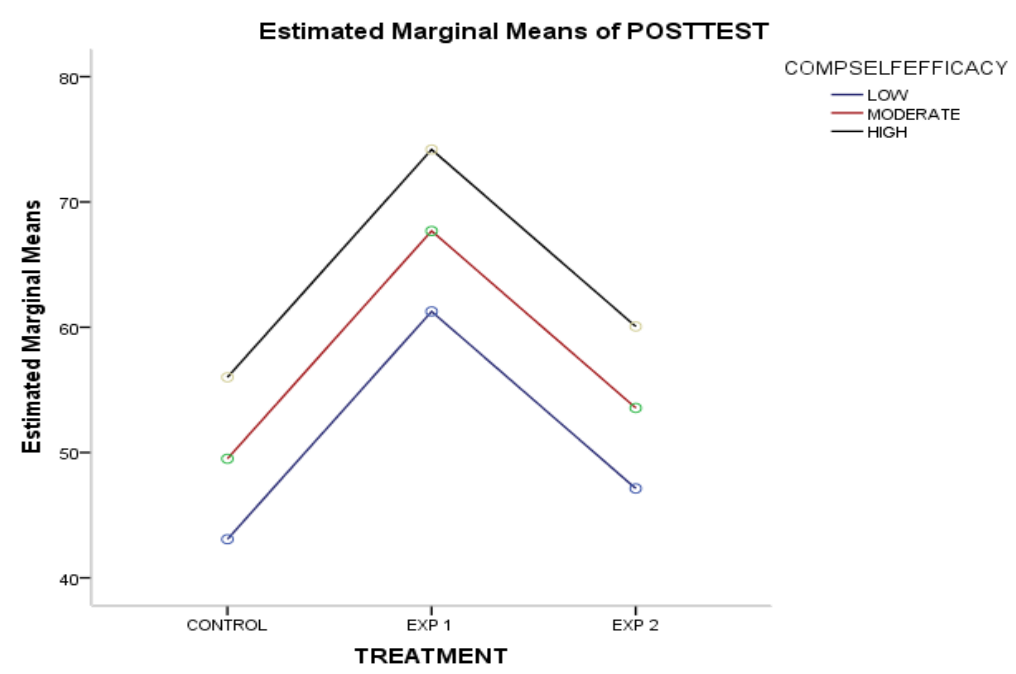

Figure 3. Pictorial representation of the interaction of treatment and computer selfefficacy on achievement

\section{Effect of the interaction effect of treatment and gender on students' achievement}

The result of the fifth hypothesis testing is also presented in Table 3 . The $H_{05}$ says that there is no significant interaction effect of treatment and gender on students' achievement in graphs. Table 3 reveals that there is significant interaction effect of 
treatment and gender on students' achievement in graphs $\left(\mathrm{F}_{(2,295)}=3.844\right.$; partial $\eta^{2}=$ 0.03). Therefore $H_{05}$ is rejected. Figure 4 shows the interaction effect.

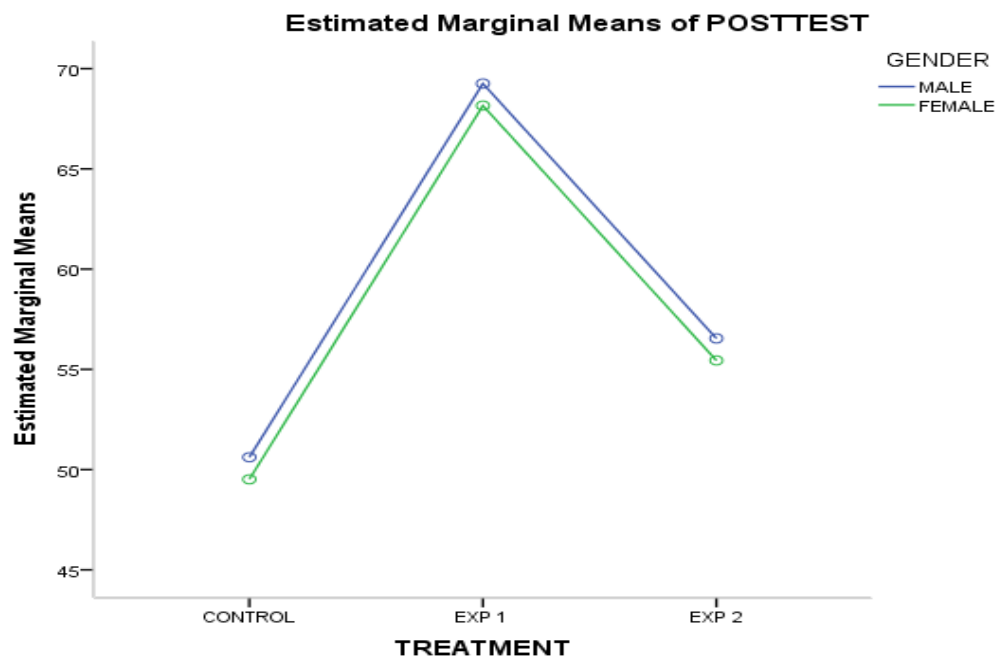

Figure 4. Pictorial representation of the interaction of treatment and gender on achievement

The achievement in EXP 1 (RUC) was higher, followed by EXP 2 (IUC). There exists significant gender difference in the achievement of all the groups in favor the male, consequence upon the large number of the sample which resulted in a raw score difference of about 733 between males and females, notwithstanding the closeness in the mean.

\section{Effect of interaction of gender and computer self-efficacy on students' achievement}

The result of the sixth hypothesis testing is also presented in Table 3 . The $H_{06}$ says that there is no significant interaction effects of gender and computer self-efficacy on students' achievement in graphs. Table 3 reveals that there is significant interaction effect of gender and computer self-efficacy on students' achievement in graphs $\left(\mathrm{F}_{(2,295)}\right.$ = 3.073; partial $\eta^{2}=0.02$ ). Therefore $H_{06}$ is rejected. Figure 5 shows the interaction effect. 


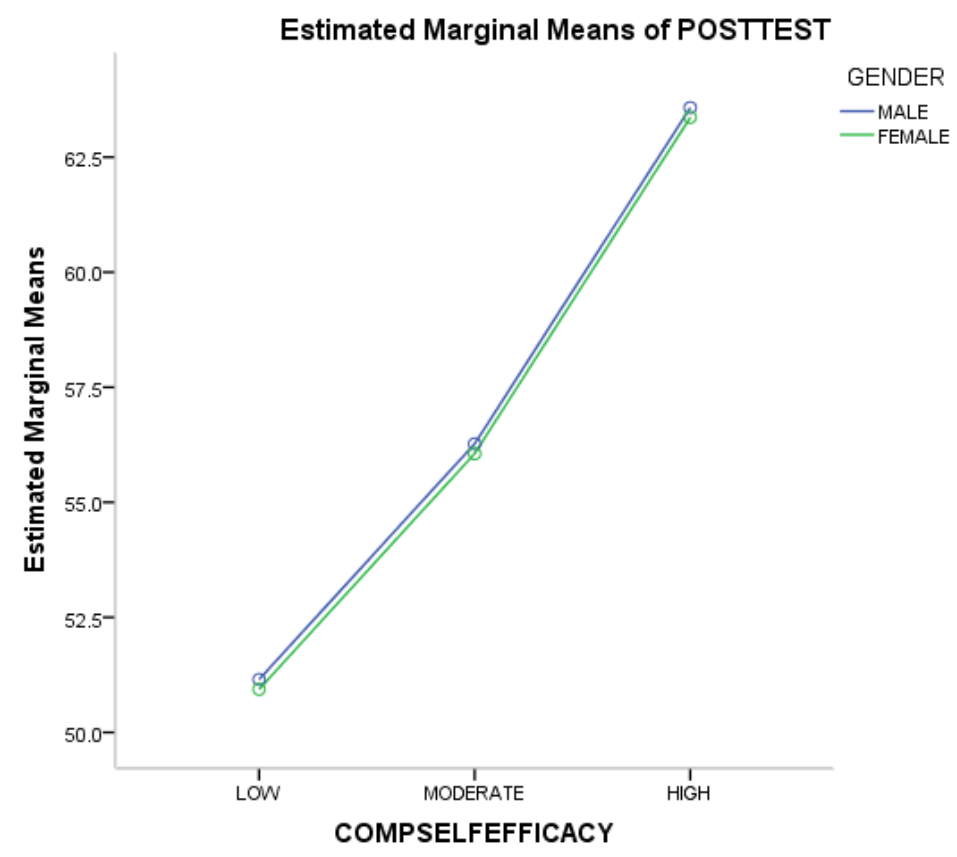

Figure 5. Pictorial representation of the interaction of gender and computer selfefficacy on achievement

\section{Effect of interaction of treatment, gender and computer self-efficacy on students' achievement}

The result of the seventh hypothesis testing is also presented in Table 3 . The $H_{07}$ says that there is no significant interaction effect of treatment, gender and computer self-efficacy on students' achievement in graphs. Table 3 reveals that there is significant interaction effect of treatment, gender and computer self-efficacy on students' achievement in graphs $\left(\mathrm{F}_{(4,295)}=2.394\right.$; partial $\left.\eta^{2}=0.33\right)$. Therefore $H_{07}$ is rejected. Figure 6 shows the interaction effect.

Estimated Marginal Means of POSTTEST

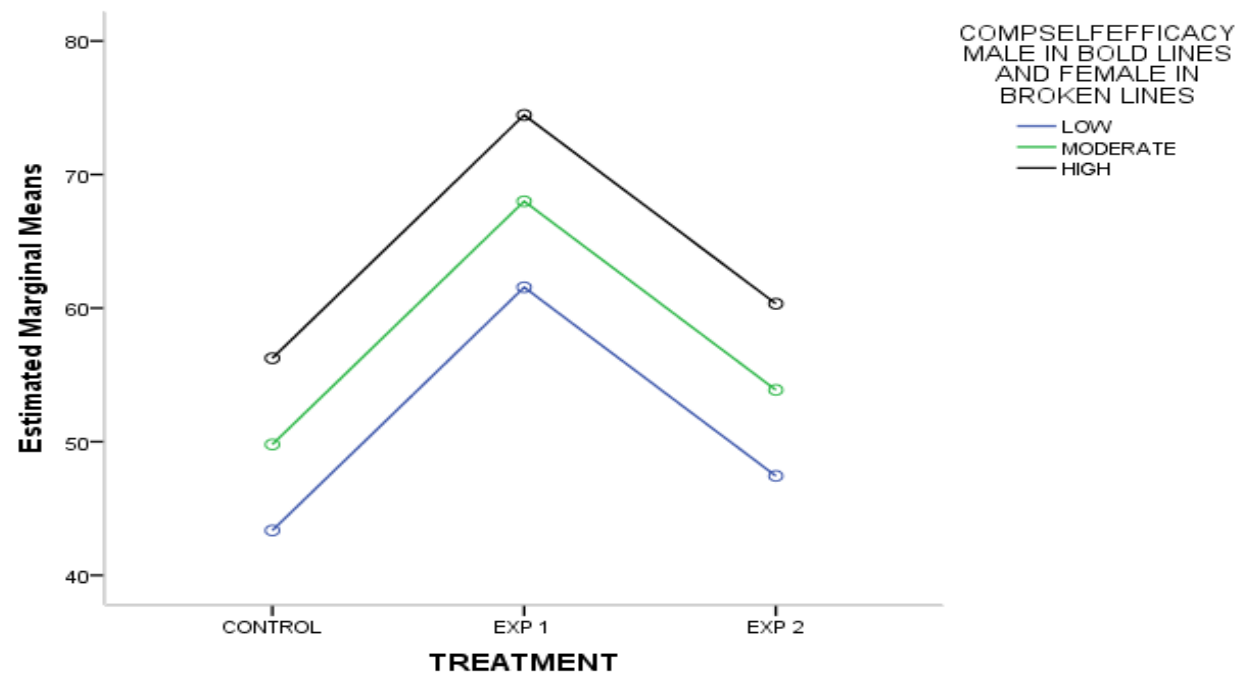

Figure 6. Pictorial representation of in the interaction of treatment, computer selfefficacy a, $d$ gender on achievement

IJEME, Vol. 2, No. 2, September 2018, 139-156. 
In Figure 6, the males with high computer self-efficacy in EXP1 (RUC) have higher mean achievement score than female while there interaction between mean achievement scores of males and females in the EXP2 (IUC) and the control groups of the high, moderate and low computer self-efficacy.

\section{Summary of Findings}

The result of the study reveals that there is a significant main effect of treatment on students' academic achievement in graphs. Computer Based Software Program Package Instruction (CBSPPI) is more effective in enhancing students' academic achievement in graphs than conventional strategy. However, subjects in Regular Users of Computer (RUC) group outclass those in Irregular Users of Computer (IUC) in achievement in graphs while IUC is more effective than conventional strategy in boosting students' academic achievement in graphs.

There is a significant main effect of computer self-efficacy on students' academic achievement in graphs. There is a significant main effect of gender on students' academic achievement in graphs and attitude towards graphs. There is a significant interaction effect of treatment and computer self-efficacy; treatment and gender; gender and computer self-efficacy; treatment, gender and computer self-efficacy on students' achievement in graphs.

\section{Discussion}

One of the major findings of this study is that there is a significant difference in achievement in graphs of students taught using Computer Based Software Program Package Instruction (CBSPPI) better than those exposed and conventional strategy. Hence Hypothesis $H_{01}$ was rejected. RUC that used a computer in learning regularly is most effective of the CBSPPI strategy for teaching graphs, followed by IUC while the conventional method is the least. Notwithstanding that the same task is performed, RUC was superior to IUC and conventional teaching strategy. This is due to the interest which frequent use of computer-generated in the learners in RUC group.

Moreover, as the computer is being used in many activities which students are aware of, they became enthusiastic to use it in learning, hence the improvement in achievement. The findings are in line with Kara \& Yesilyurt (2007), Ragasa (2008), Kausar et al. (2008), Yesilyurt (2010), and Yusuf \& Afolabi (2010) who observed that computer-assisted instruction strategy is very useful in improving cognitive achievement. It also supports the findings of Williams \& Leader (2010) who posited that the use of computer-assisted instruction helps learners in understanding concept and acquiring the relevant skills of graphs and table as well as imparting the desired learning experience. Similarly, studies conducted by Afzal et al. (2014) and Gambari et al. (2014) revealed that used adequately of well-prepared computer-assisted instructional packages induces higher academic achievement and attitude towards mathematics of learners which supports the findings of this study.

Three categories of computer self-efficacy, high, moderate and low were used in the study. The result shows that there is the significant main effect of computer selfefficacy on students' achievement in graphs. It is on this basis $H_{02}$ was rejected. The mean achievement scores of students in the three groups are significantly different in favor students with high computer self-efficacy, followed by moderate and finally low. The students with high computer self-efficacy have higher mean achievement score, higher than those with moderate self-efficacy and those with moderate self-efficacy have higher mean achievement score than those with low computer self-efficacy. The 
findings of this study support that of Ersoy \& Akbulut (2014) who affirmed that there exists a high correlation between computer self-efficacy and achievement.

The finding of this study reveals that there is a significant main effect of gender on achievement in graphs in favor of the male gender, resulting in not accepting $H_{03}$. Though, the mean achievement score is very close; male: 57.421 and female: 56.309 , the F ratio of $\mathrm{F}_{(1,295)}=7.035 ; p<0.05$ as against a critical value of $\left(\mathrm{F}_{(1,295)}=3.84 ; p<0.05\right.$, and the raw scores difference of about 733, prove that there is a significant main effect of gender on students' achievement in graphs. The size of sample 143 for female and 153 for males affected the mean difference and contributed to the significance of the calculated value of F-ratio. The achievement scores of male and female gender are significantly different. The mean achievement score of the male students is slightly higher than that of their female counterparts, in general. These findings confirm that of Else-Quest et al. (2010) who averred there exists gender disparity in achievement in mathematics. It also contradicts the findings of Oludipe (2012), Abubakar \& Oguguo (2011), and Udousoro(2011) who claimed that there exists no significant gender difference in academic achievement in mathematics. The existence of gender disparity in achievement in graphs notwithstanding the use of interactive basic programme package and graphic organizer is large because males are more focused and able to sustain the duration and rigor required to learn the concepts properly. It is also a result of previous knowledge, though the groups were at the same level before the experiments it is obvious that there had existed a slight difference in males and females students' achievement and attitude to mathematics before the treatments.

The result shows that there is a significant interaction effect of treatment and computer self-efficacy on students' Achievement, hence $H_{04}$ is rejected. Students with high computer self-efficacy had higher achievement scores in an all groups. This shows that computer self-efficacy relates positively to achievements. The findings of this study support that of Ersoy \& Akbulut (2014) who affirmed that there exists a high correlation between computer self-efficacy and achievement. There is a significant interaction effect of treatment and gender on students' achievement in graphs. Hence $H_{05}$ is rejected. In all the groups' male students have higher scores than the females in achievement test. There is a significant interaction effect of gender and computer self-efficacy on students' achievement in graphs, hence $H_{06}$ is rejected. Fallan \& Opstad (2016) supported the findings of this study that there exist significant interaction effect of gender and selfefficacy in favor of males. There is also a significant interaction effect of treatment, gender and computer self-efficacy on students' achievement in graphs. Therefore $H_{07}$ is rejected. The study reveals that both male and female students taught with CBSPPI score higher than those taught with conventional methods in achievement in graphs.

\section{CONCLUSION}

The study established that CBSPPI teaching strategy for regular users RUC, as well as irregular users IUC, are both useful in improving students' achievement in graphs. This is because in both cases the teaching strategy enables learners to develop self-confidence regarding their ability and self-effort. The inbuilt drill and interactive exercises in the interactive help the learners understand faster and learn with ease. Though significant improvement in achievement was observed, it was also noted that there still exist gender difference in the achievement of learners in all the groups. The use of Computer Based Software Program Package Instruction (CBSPPI) in teachings mathematics produced excellent results and should be used by the teachers.

IJEME, Vol. 2, No. 2, September 2018, 139-156. 


\section{REFERENCES}

Abubakar, R. B., \& Oguguo, O. D. (2011). Age and Gender as Predictors of Academic Achievement of College Mathematics and Science Students. Journal of Educational and Social Research, 1(2), 89-93.

Afzal, M., Gondal, B., \& Fatima, N. (2014). The Effect of Computer Based Instructional Technique for the Learning of Elementary Level Mathematics among High, Average, and Low Achievers. International Journal of Education and Development using ICT, 10(4), 47-59.

Akinsola, M. K., \& Odeyemi, E. O. (2014). Effects of Mnemonic and Prior Knowledge Instructional Strategies on Students' Achievement in Mathematics. International Journal of Education and Research, 2(7), 675-688.

Aoyama, K. (2007). Investigating a Hierarchy of Students' Interpretations of Graphs. International Electronic Journal of Mathematics Education, 2(3), 298-318.

Areelu, F., \& Akinsola, M. K. (2014). Influence of Tiered Lesson and Group Personalization Instructional Strategies on Senior Secondary Students' Achievement in Mathematics. European Scientific Journal, 10(16), 474-497.

Asikhia, O. A. (2010). Students and Teachers' Perception of the Causes of Poor Academic Performance in Ogun State Secondary Schools [Nigeria]: Implications for Counseling for National Development. European Journal of Social Sciences, 13(2), 229-242.

Berg, C. A., \& Smith, P. (1994). Assessing Students' Abilities to Construct and Interpret Line Graphs: Disparities Between Multiple-Choice and Free-Response Instruments. Science Education, 78(6), 527-554.

Else-Quest, N. M., Hyde, J. S., \& Linn, M. C. (2010). Cross-National Patterns of Gender Differences in Mathematics: A Meta-analysis. Psychological Bulletin, 136(1), 103-127.

Ersoy, M., \& Akbulut, Y. (2014). Cognitive and Affective Implications of Persuasive Technology Use on Mathematics Instruction. Computers \& Education, 75, 253-262.

Fallan, L., \& Opstad, L. (2016). Student Self-Efficacy and Gender-Personality Interactions. International Journal of Higher Education, 5(3), 32-44.

Faulkner, L. R. (2008). Foundations for Success: National Mathematics Advisory Panel (Final Report Briefing). Washington, DC: US Department of Education.

Gambari, I. A., Ezenwa, V. I., \& Anyanwu, R. C. (2014). Comparative Effects of Two Modes of Computer-Assisted Instructional Package on Solid Geometry Achievement. Contemporary Educational Technology, 5(2), 110-120.

Hooper, S., \& Rieber, L. P. (1995). Teaching with Technology. In A. C. Ornstein (Ed)., Teaching: Theory into Practice (pp. 154-170). Needham Heights, MA: Allyn and Bacon.

Isman, A. (2011). Instructional Design in Education: New Model. Turkish Online Journal of Educational Technology-TOJET, 10(1), 136-142.

Kara, Y., \& Yesilyurt, S. (2007). Assessing the Effects of Tutorial and Edutainment Software Programs on Students' Achievements, Misconceptions and Attitudes towards Biology. Asia-Pacific Forum on Science Learning and Teaching, 8(2), 1-22.

Kausar, T., Choudhry, B. N., \& Gujjar, A. A. (2008). A Comparative Study to Evaluate the Effectiveness of Computer Assisted Instruction (CAI) versus Class Room Lecture (CRL) for Computer Science at ICS Level. Turkish Online Journal of Educational TechnologyTOJET, 7(4), 19-28. 
Knuth, E. J. (2000). Understanding Connections between Equations and Graphs. The Mathematics Teacher, 93(1), 48-53.

Konold, C., \& Higgins, T. (2003). Reasoning about Data. In J. Kilpatrick, W. Martins, \& D. Schifter (Eds.), A Research Companion to Principles and Standard for School Mathematics. Reston, VA: National Council of Teachers of Mathematics.

Oludipe, D. L. (2012). Gender Difference in Nigerian Junior Secondary Students' Academic Achievement in Basic Science. Journal of Educational and Social Research, 2(1), 93-99.

Parmar, R. S., \& Signer, B. R. (2005). Sources of Error in Constructing and Interpreting Graphs: A Study of Fourth-and Fifth-grade Students with LD. Journal of Learning Disabilities, 38(3), 250-261.

Ragasa, C. Y. (2008). A Comparison of Computer-Assisted Instruction and the Traditional Method of Teaching Basic Statistics. Journal of Statistics Education, 16(1).

Reyna, V. F., \& Brainerd, C. J. (2007). The Importance of Mathematics in Health and Human Judgment: Numeracy, Risk Communication, and Medical Decision Making. Learning and Individual Differences, 17(2), 147-159.

Roth, W. M., \& McGinn, M. K. (1997). Graphing: Cognitive Ability or Practice?.Science Education, 81(1), 91-106.

Tella, A. (2007). The Impact of Motivation on Student's Academic Achievement and Learning Outcomes in Mathematics Among Secondary School Students in Nigeria. Eurasia Journal of Mathematics, Science \& Technology Education, 3(2), 149-156.

Udousoro, U. J. (2011). The Effects of Gender and Mathematics Ability on Academic Performance of Students in Chemistry. African Research Review, 5(4), 201-213.

Vernadakis, N., Avgerinos, A., Tsitskari, E., \& Zachopoulou, E. (2005). The Use of Computer Assisted Instruction in Preschool Education: Making Teaching Meaningful.Early Childhood Education Journal, 33(2), 99-104.

WAEC. (2013). Resume from the Mathematics. West African Examination Council Chief Examiners' Report. Lagos: West African Examination Council.

WAEC. (2014). Resume of All the Report from the Mathematics and Applied Science Sector. West African Examination Council Chief Examiners' Report. Lagos: West African Examination Council.

WAEC. (2016). Resume of Mathematics. West African Examination Council Chief Examiners' Report. Lagos: West African Examination Council.

WAEC. (2017). General Resume. West African Examination Council Chief Examiners' Report. Lagos: West African Examination Council.

Williams, D. A., \& Leader, L. (2006). Graphing Calculators and Their Effect on Students' Understanding of Functions. Dissertation. Valdosta: Valdosta State University.

Yesilyurt, M. (2010). Meta Analysis of the Computer Assisted Studies in Science and Mathematics: A Sample of Turkey. Turkish Online Journal of Educational TechnologyTOJET, 9(1), 123-131.

Yusuf, M. O., \& Afolabi, A. O. (2010). Effects of Computer Assisted Instruction (CAI) on Secondary School Students' Performance in Biology. Turkish Online Journal of Educational Technology-TOJET, 9(1), 62-69. 